\title{
Editorial
}

Psychotherapy and Psychosomatics

\section{Culture, Psychosomatics and Substance Abuse: The Example of Body Image Drugs}

\author{
Gen Kanayama a, b James I. Hudson ${ }^{a}$ b Harrison G. Pope Jr. a, b \\ a Biological Psychiatry Laboratory, McLean Hospital, Belmont, Mass., and 'bepartment of Psychiatry, \\ Harvard Medical School, Boston, Mass., USA
}

Patterns of illicit drug use vary widely around the world. For example, one recent survey [1] found lifetime cannabis use among $41.9 \%$ of respondents in New Zealand, but only $6.6 \%$ of respondents in Italy and $1.5 \%$ in Japan. Cocaine was reported by $16.2 \%$ of respondents in the USA, versus $4.1 \%$ in Spain and $0.0 \%$ in the People's Republic of China. Favored drugs of abuse may also rank differently within different countries. Japan, for instance, has experienced three major epidemics of methamphetamine abuse over the last 50 years [2, 3], but shows a low prevalence of many other forms of drug abuse that are widespread elsewhere [4]. Clearly, factors such as drug availability, government enforcement policies and national healthcare systems contribute to these figures, but one must also acknowledge the critical role of culture [5]. Culture influences not only attitudes towards illicit drug use in general, but also which particular drugs people choose to use; a drug effect sought by one population might have little appeal for another. As one example of this little-studied issue, we explore here a form of drug abuse that is strikingly asymmetric across cultures: the use of 'body image drugs' such as anabolic-androgenic steroids (AAS).

The AAS are a family of hormones that includes the natural male hormone testosterone and its numerous synthetic derivatives [6]. In high doses, AAS permit users (who are mostly [7], though not always [8], male) to achieve marked increases in muscularity and decreases in body fat, often well beyond the limits attainable by natural means [9] (fig. 1). Prior to about 1980, AAS use was primarily confined to elite competitive athletes, but in the last 30 years, these drugs have spread into the general population [10]. Now, AAS have been used worldwide by millions of men, many of whom have no athletic aspirations, but simply want to look more muscular $[6,11]$. Such men often also use various other body image drugs to gain muscle or lose body fat [12], including substances such as human growth hormone, thyroid hormones, insulin, clenbuterol and ephedrine $[13,14]$. At present, however, most of the available epidemiological data are confined to AAS. Concern about the dangers of these drugs has mounted over the last decade [10], with increasing recognition of their possible cardiac $[13,15]$, neuroendocrine [6] and psychiatric effects [16], including the frequent development of dependence syndromes [17-19].

The prevalence of AAS use shows striking geographic variation. AAS abuse is a particularly common problem in Scandinavia [20-23], followed perhaps next by the USA $[24,25]$, then the British Commonwealth countries [26-30], Brazil [31] and the rest of Western Europe [32-

\section{KARGER}

Fax +4161306 1234 E-Mail karger@karger.ch www.karger.com
(C) 2012 S. Karger AG, Basel

0033-3190/12/0812-0073\$38.00/0

Accessible online at:

www.karger.com/pps
Harrison G. Pope Jr., MD

McLean Hospital

115 Mill Street

Belmont, MA 02478 (USA)

Tel. +1 617855 2911, E-Mail hpope@ @clean.harvard.edu 
Fig. 1. a Photograph of Eugene Sandow, a famous bodybuilder from the era prior to AAS, showing the approximate maximum muscularity attainable without AAS. http://commons.wikimedia.org/wiki/ File:Eugene_Sandow.jpg (accessed June 12, 2011). b A modern bodybuilder who has extensively used AAS.
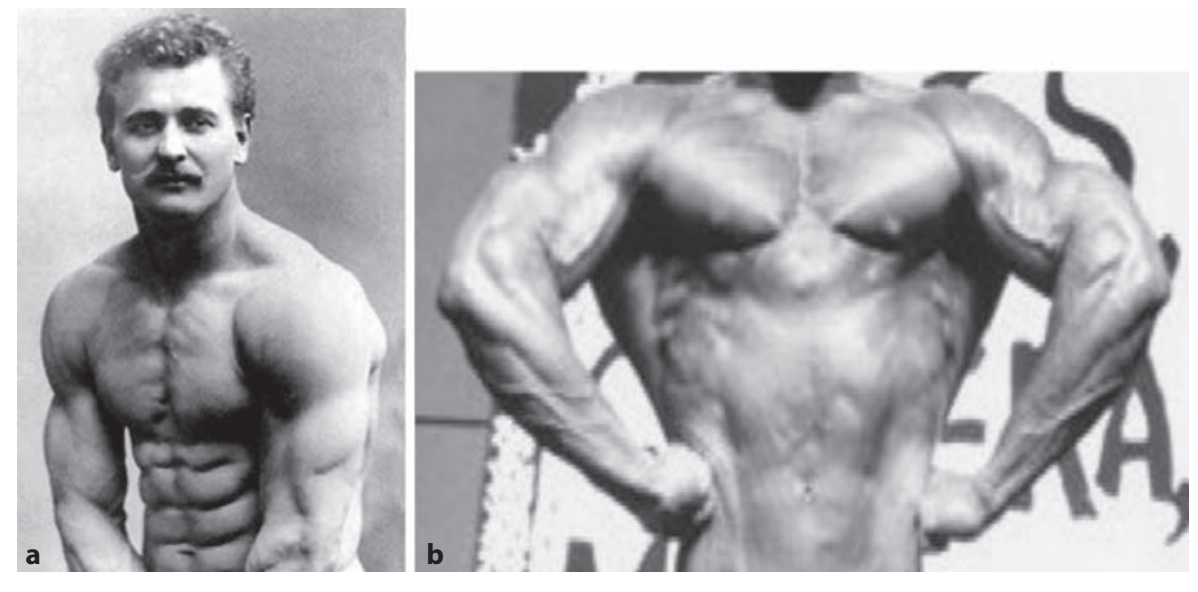

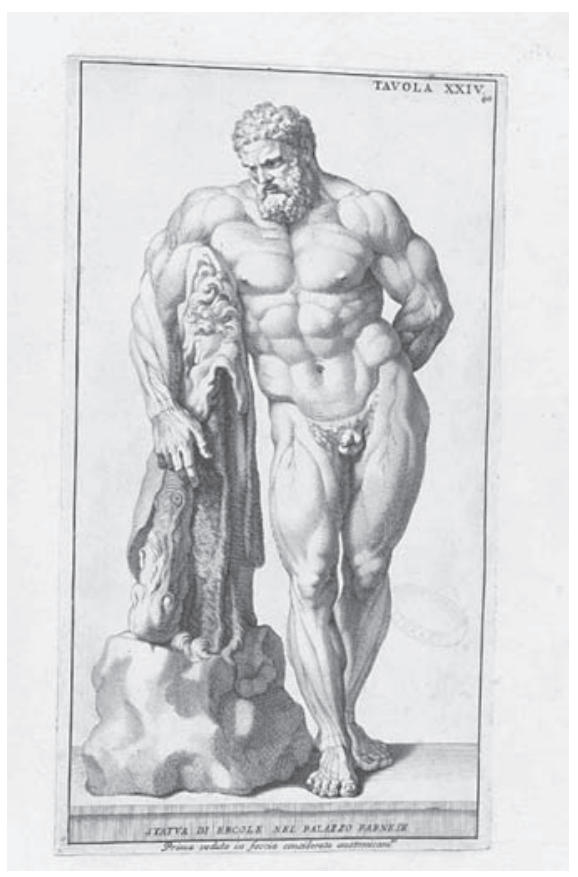

Fig. 2. Drawing of the Farnese statue of Hercules from Bernardino Genga's Anatomia per uso et intelligenza del disegno (Rome, Domenico de Rossi, 1691). United States National Library of Medicine, Bethesda, Md., USA. From Historical Anatomies on the Web, plate 40. http://www.nlm.nih.gov/exhibition/historicalanatomies/ Images/1200_pixels/genga_40.jpg (accessed June 12, 2011).

34]. By contrast, AAS abuse is rare in the Far East, with only a handful of reports of illicit AAS use in countries such as China, Korea or Japan [35-38]. Indeed, in a recent study where we administered questionnaires to $118 \mathrm{Chi}$ nese men aged 21-38 years at a Beijing graduate school [39], none reported having ever used AAS or having even known of an acquaintance who had, even though AAS are legally available over the counter in Beijing pharmacies. Contrast this finding with Norway, where AAS are illegal, yet $28 \%$ of teenage students in one study knew an acquaintance who had used these drugs [21]. Admittedly, part of this difference reflects the lower overall ambient levels of substance abuse in the Far East. But this explanation alone is insufficient because other types of illicit drug use are well documented there: opioids in China [40], methamphetamine, cannabis and opioids in Korea [41], or methamphetamine and inhalants in Japan [3]. Why then are AAS almost completely restricted to the West?

We suggest that the explanation dates back millennia and is grounded in psychosomatics. Western cultures have extolled muscularity since ancient times, as illustrated by Samson in the Bible, or by the supernaturally muscular gods of ancient Greece and Rome. Consider for example the ancient Farnese statue of Hercules, now at the Museo Archeologico Nazionale Napoli (http://www. marketplace.it/museo.nazionale/emuseo_home.htm) and depicted in a 17th-century drawing by famed Italian anatomist Bernardino Genga (fig. 2). Working centuries before AAS were discovered, Genga had never seen a real man who looked remotely like Hercules, yet his drawing eerily anticipates the modern AAS-using bodybuilder in figure $1 \mathrm{~b}$. The mythic traditions of Scandinavia - the region with perhaps the greatest contemporary epidemic of AAS use - arguably place an even stronger emphasis on muscularity, as exemplified by the gods of Norse mythology. Look, for example, at Füssli's 1788 painting of Thor battering the Midgard Serpent (fig. 3), based on the story in the medieval Prose Edda [42]. Like Genga, working long before the AAS era, Füssli had never seen an actual 
Fig. 3. Johann Heinrich Füssli's Der Kampf des Thor mit der Schlange des Midgard (Holland, 1788). Royal Academy of Arts, London, UK. http://en.wikipedia.org/wiki/ File:Johann_Heinrich_F\%C3\%BCssli_011. jpg (accessed June 12, 2011).

Fig. 4. Eitaku Kobayashi's Izanagi and Izanami (Japan, 1885). Museum of Fine Arts, Boston, Mass., USA. http://commons. wikimedia.org/wiki/File:Kobayashi_ Izanami_and_izanagi.jpg (accessed June 12, 2011).
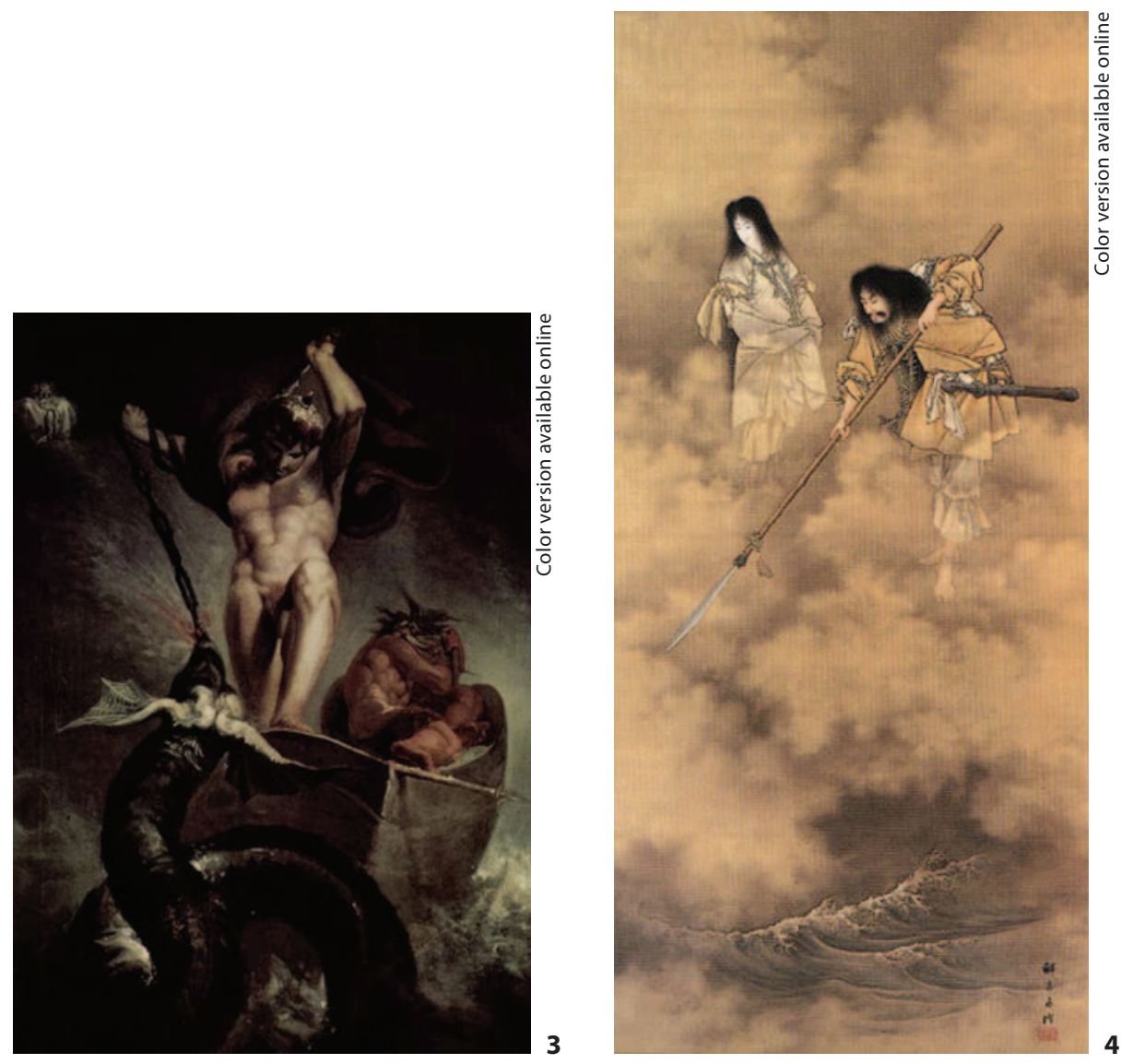

man who approached the proportions of the image that he painted - yet both Thor and his boatman Hymir, prone in the bow of the boat, look like AAS-using championship bodybuilders. These same venerable Western traditions of muscularity have continued to flourish into modern times, as illustrated by muscular action toys for children [43], male bodies in magazine advertisements [44], Hollywood movie characters [45] and numerous other images.

By contrast, the cultural legacy of the Far East is almost devoid of these traditions or images. Compare, for example, the deity Izanagi (fig. 4), who with his sister Izanami created the islands of Japan in the Kojiki epic [46], or Japan's oldest known sculpture of Buddha, constructed in the year 609, at the Asuka-dera in Asuka (fig. 5). These deities are fully clothed, with no suggestion of enhanced muscularity. Similarly, in modern-day China or Japan, one rarely sees images of muscularity. The hero of an Asian action movie may be a lean martial artist, but not a muscle-bound hunk like Hollywood's Conan the Barbarian. These Eastern cultural traditions, like those of the West, hark back to ancient times. For example, as we have detailed elsewhere [47], the highly influential Analects of Confucius [48], written more than 2,000 years ago, link masculinity to intellect, refinement and virtuousness, but not to brawn.

The effects of these contrasting traditions are illustrated by the findings of recent studies using a computerized test of body image where college-age men were asked to select the male body that they thought was most appealing to women in their respective cultures. In response to this question, men in the USA, Austria and France selected a male image with about $10 \mathrm{~kg}$ more muscle than an average man in their societies [49], whereas men in Taiwan chose an image with very little added muscle, correctly recognizing that women were not attracted to a highly muscular male body [47] (fig. 6). This difference between East and West showed a striking effect size (Cohen's $d=0.9$ ) [50], and it becomes even more impressive when one considers that many other types of body image concerns, by contrast, easily span cultural boundaries [51, 52]. In fact, young Japanese men actually appear to show higher levels 


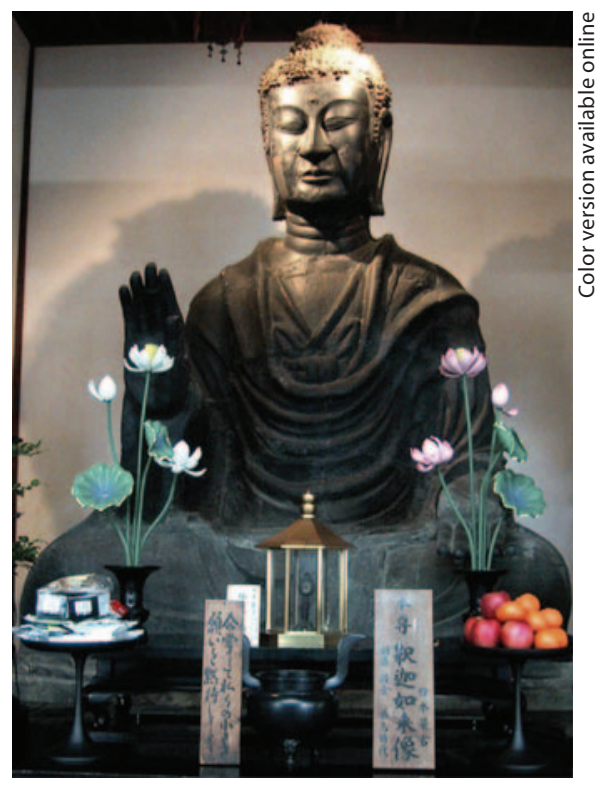

Fig. 5. Kuratsukuri-no-Tori's statue of Buddha at the Asuka-dera in Asuka, Japan (609 A.D.). http://en.wikipedia.org/wiki/File: Asuka_dera_daibutsu.jpg (accessed July 8, 2011).

of overall body dissatisfaction than their counterparts elsewhere [53,54], even though they do not seem particularly dissatisfied with their muscles [55].

Will body image drugs such as AAS eventually infiltrate the Far East? That will depend on whether Western attitudes towards muscularity, augmented by the forces of media and marketing, can trump the equally venerable opposing attitudes in Asia. Confucian traditions remain strong in East Asia [47], and we doubt that they will easily be overturned by the influences of Hollywood. Similarly, Eastern traditions of self-cultivation [56] such as Japanese shugyō - 'forging the spirit' through lengthy mental and physical training - may militate against the 'easy' path of simply taking a drug to alter one's body. Indeed, the very notion of merely enhancing the body while neglecting training of the mind or spirit is incompatible with longstanding traditions such as the bush $i$ way in Japanese martial arts [57].

Nevertheless, looking at the somewhat analogous case of eating disorders, where body image concerns are in many ways the obverse of concerns about muscularity [58], we see that these disorders have begun to appear among men in Japan [59, 60] and China [61, 62], albeit more recently and less commonly than among men in Europe and America [63]. Clearly, cultural attitudes to-

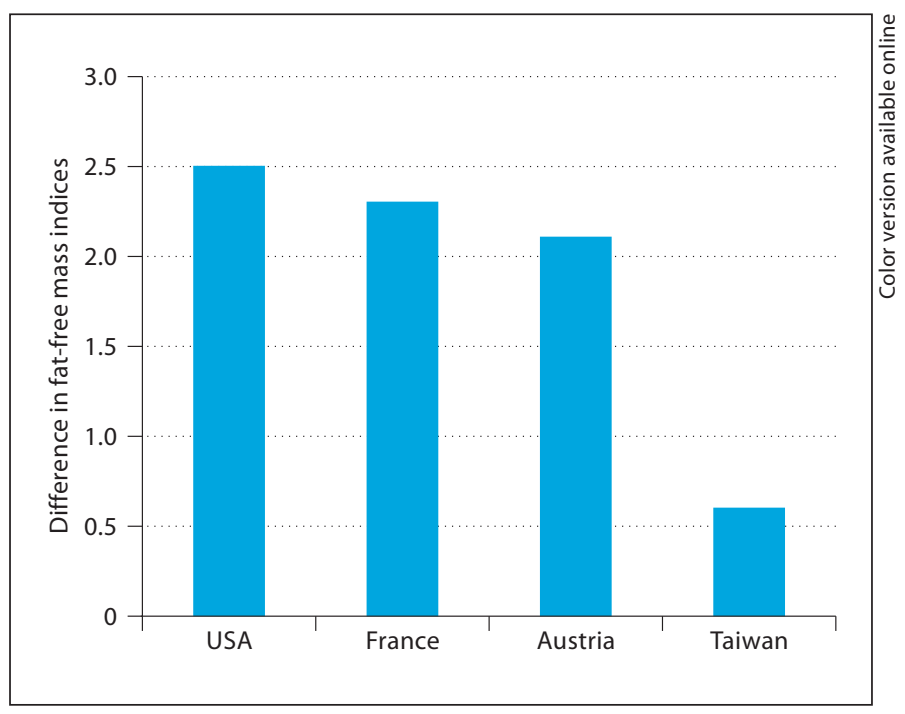

Fig. 6. Discrepancy between the perceived muscularity of an 'average man' versus the muscularity of 'the male body that women prefer the most', as rated by men in the USA, France, Austria and Taiwan. Figure adapted, with permission, from Yang et al. [47].

wards the body image are not static, and shifting global trends may well alter the distribution of body image drugs in future decades.

What about other forms of drug use? Unlike the body image drugs discussed in our example above, most other drugs of abuse are sought for their acute intoxicating effect, or 'high', and for millennia, cultures have helped to dictate peoples' preferred intoxicant. In 430 B.C., for example, Herodotus documented the practice of the Persians to consider affairs of weight while drunk on alcohol; if they first made a decision while sober, they would later deliberately reconsider it under the influence of wine [64]. Conversely, many deeply spiritual traditional societies have long valued hallucinogenic plants - peyote, psilocybin mushrooms, ayahuasca or iboga - for their entheogenic effects [65-67]. One might speculate about countless other possible cultural influences. Perhaps achievement-oriented East Asians value the mentally 'sharp' high of methamphetamine more than, say, the mentally 'dull' high of cannabis [68]. Perhaps societies with high levels of anxiety breed more sedative-hypnotic drug abuse than societies without. Importantly, in any such comparison, one must also take into account possible cultural differences in willingness to disclose substance use [69]. All these issues remain little studied. 
And what about new drugs on the horizon? Progress in pharmacology will likely yield not only new intoxicants, but also cognitive enhancers [70], drugs that may someday allow individuals to 'dial' their own body weight [71], and other substances with a variety of psychosomatic properties [72]. These and other drugs will increasingly be diffused on the Internet, with the consequent tendency towards a globalization of cultures [13, 73-75].
How, in the brave new world of expanding pharmacological options and growing electronic access, will people in different cultures choose from the menu available to them? These issues, and indeed many elements of our above discussion, remain speculative. Clearly, however, the interface between culture and drug abuse will remain a fertile area for future exploration, with implications for public health, international policy and ethics [76].

\section{References}

$\checkmark 1$ Degenhardt L, Chiu WT, Sampson N, Kessler RC, Anthony JC, Angermeyer M, Bruffaerts R, de Girolamo G, Gureje O, Huang Y, Karam A, Kostyuchenko S, Lepine JP, Mora ME, Neumark Y, Ormel JH, Pinto-Meza A, Posada-Villa J, Stein DJ, Takeshima T, Wells JE: Toward a global view of alcohol, tobacco, cannabis, and cocaine use: findings from the WHO World Mental Health Surveys. PLoS Med 2008;5:e141.

-2 Grelotti DJ, Kanayama G, Pope HG Jr: Remission of persistent methamphetamineinduced psychosis after electroconvulsive therapy: presentation of a case and review of the literature. Am J Psychiatry 2010;167:1723.

- 3 Wada K, Ozaki S, Kondo A: Current situation of and the political measures for drug abuse/dependence (in Japanese). Nihon Arukoru Yakubutsu Igakkai Zasshi 2008;43: 120-131.

-4 Tominaga M, Kawakami N, Ono Y, Nakane Y, Nakamura Y, Tachimori H, Iwata N, Uda $H$, Nakane $H$, Watanabe M, Naganuma $Y$, Furukawa TA, Hata Y, Kobayashi M, Miyake Y, Takeshima T, Kikkawa T: Prevalence and correlates of illicit and non-medical use of psychotropic drugs in Japan: findings from the World Mental Health Japan Survey 2002-2004. Soc Psychiatry Psychiatr Epidemiol 2009;44:777-783.

5 Greberman SB, Wada K: Social and legal factors related to drug abuse in the United States and Japan. Public Health Rep 1994;109:731737.

6 Kanayama G, Hudson JI, Pope HG Jr: Illicit anabolic-androgenic steroid use. Horm Behav 2010;58:111-121.

7 Kanayama G, Gruber AJ, Pope HG Jr, Borowiecki JJ, Hudson JI: Over-the-counter drug use in gymnasiums: an underrecognized substance abuse problem? Psychother Psychosom 2001;70:137-140.

8 Gruber AJ, Pope HG Jr: Psychiatric and medical effects of anabolic-androgenic steroid use in women. Psychother Psychosom 2000; 69:19-26.

-9 Kouri EM, Pope HG Jr, Katz DL, Oliva P: Fatfree mass index in users and nonusers of anabolic-androgenic steroids. Clin J Sport Med 1995;5:223-228.
10 Kanayama G, Hudson JI, Pope HG Jr: Longterm psychiatric and medical consequences of anabolic-androgenic steroid abuse: a looming public health concern? Drug Alcohol Depend 2008;98:1-12.

11 Parkinson AB, Evans NA: Anabolic androgenic steroids: a survey of 500 users. Med Sci Sports Exerc 2006;38:644-651.

12 Kanayama G, Pope HG Jr, Hudson JI: 'Body image' drugs: a growing psychosomatic problem. Psychother Psychosom 2001;70: 61-65.

13 Brennan BP, Kanayama G, Hudson JI, Pope HG Jr: Illicit human growth hormone abuse in male weightlifters. Addict Behav 2011;20: 9-13.

14 Hildebrandt T, Alfano L, Langenbucher JW: Body image disturbance in 1,000 male appearance- and performance-enhancing drug users. J Psychiatr Res 2010;44:841-846.

15 Baggish AL, Weiner RB, Kanayama G, Hudson JI, Picard MH, Hutter AM Jr, Pope HG Jr: Long-term anabolic-androgenic steroid use is associated with left ventricular dysfunction. Circ Heart Fail 2010;3:472-476.

16 Pope HG Jr, Katz DL: Psychiatric effects of exogenous anabolic-androgenic steroids; in Wolkowitz OM, Rothschild AJ (eds): Psychoneuroendocrinology. The Scientific Basis of Clinical Practice. Washington, American Psychiatric Press, 2003, pp 331-358.

17 Kanayama G, Brower KJ, Wood RI, Hudson JI, Pope HG Jr: Anabolic-androgenic steroid dependence: an emerging disorder. Addiction 2009;104:1966-1978.

18 Kanayama G, Brower KJ, Wood RI, Hudson JI, Pope HG Jr: Treatment of anabolic-androgenic steroid dependence: emerging evidence and its implications. Drug Alcohol Depend 2010;109:6-13.

19 Pope HG Jr, Kean J, Nash A, Kanayama G Samuel DB, Bickel WK, Hudson JI: A diagnostic interview module for anabolic-androgenic steroid dependence: preliminary evidence of reliability and validity. Exp Clin Psychopharmacol 2010;18:203-213.

20 Nilsson S, Spak F, Marklund B, Baigi A, Allebeck P: Attitudes and behaviors with regards to androgenic anabolic steroids among male adolescents in a county of Sweden. Subst Use Misuse 2004;39:1183-1197.
21 Pallesen S, Jøsendal O, Johnsen BH, Larsen $\mathrm{S}$, Molde $\mathrm{H}$ : Anabolic steroid use in high school students. Subst Use Misuse 2006;41: 1705-1717.

-22 Skårberg K, Nyberg F, Engström I: Multisubstance use as a feature of addiction to anabolic-androgenic steroids. Eur Addict Res 2009; 15:99-106.

23 Thiblin I, Petersson A: Pharmacoepidemiology of anabolic androgenic steroids: a review. Fundam Clin Pharmacol 2005;19:2744.

24 Johnston LD, O'Malley PM, Bachman JG, Schulenberg JE: Monitoring the future national survey results on drug use, 1975-2009. Vol II. College students and adults ages 1950. NIH Publ No. 10-7585. Bethesda, National Institute on Drug Abuse, 2010. http://monitoringthefuture.org/new.html (accessed June 12, 2011).

25 McCabe SE, Brower KJ, West BT, Nelson TF, Wechsler H: Trends in non-medical use of anabolic steroids by US college students: results from four national surveys. Drug Alcohol Depend 2007;90:243-251.

26 Baker JS, Graham MR, Davies B: Steroid and prescription medicine abuse in the health and fitness community: a regional study. Eur J Intern Med 2006;17:479-484.

27 Copeland J, Peters R, Dillon P: A study of 100 anabolic-androgenic steroid users. Med J Aust 1998;168:311-312.

28 Handelsman DJ, Gupta L: Prevalence and risk factors for anabolic-androgenic steroid abuse in Australian high school students. Int J Androl 1997;20:159-164.

29 Goldfield GS, Woodside DB: Body image, disordered eating, and anabolic steroids in male bodybuilders: current versus former users. Phys Sportsmed 2009;37:111-114.

30 Melia P, Pipe A, Greenberg L: The use of anabolic-androgenic steroids by Canadian students. Clin J Sport Med 1996;6:9-14.

- 31 Galduróz JC, Noto AR, Nappo SA, Carlini EA: Household survey on drug abuse in Brazil: study involving the 107 major cities of the country - 2001. Addict Behav 2005;30:545556. 
\$2 Kokkevi A, Fotiou A, Chileva A, Nociar A, Miller P: Daily exercise and anabolic steroids use in adolescents: a cross-national European study. Subst Use Misuse 2008;43:2053-2065.

- 33 Rachoń D, Pokrywka L, Suchecka-Rachoń K: Prevalence and risk factors of anabolic-androgenic steroids (AAS) abuse among adolescents and young adults in Poland. Soz Praventivmed 2006;51:392-398.

34 Wanjek B, Rosendahl J, Strauss B, Gabriel $\mathrm{HH}$ : Doping, drugs and drug abuse among adolescents in the State of Thuringia (Germany): prevalence, knowledge and attitudes. Int J Sports Med 2007;28:346-353.

- 35 Takahashi M, Tatsugi T, Kohno Y: Telephone counseling of athletes abusing anabolic-androgenic steroids. J Sports Med Phys Fitness 2007:47:356-360

-36 Takayanagi A, Kobayashi K, Hashimoto K, Kato R, Masumori N, Itoh N, Tsukamoto T: Case of androgenic-anabolic steroid abuse caused hypogonadotropic hypogonadism (in Japanese). Nippon Hinyokika Gakkai Zasshi 2008;99:729-732.

37 Takahashi M: A case of nail destruction as a possible side effect of anabolic-androgenic steroid doping (in Japanese). Nihon Tairyoku Igakkai 1994;43:66-74.

38 Takahashi M: Gynecomastia as a side effect of anabolic-androgenic steroid doping in a Japanese amateur bodybuilder (in Japanese). Nihon Tairyoku Igakkai 1996;45:237-244.

- 39 Yang CF, Gray PB, Zhang J, Pope HG Jr: Second to fourth digit ratios, sex differences, and behavior in Chinese men and women. Soc Neurosci 2009;4:49-59.

40 Lu L, Wang X: Drug addiction in China. Ann NY Acad Sci 2008;1141:304-317.

-41 Chung H, Park M, Hahn E, Choi H, Choi H, Lim M: Recent trends of drug abuse and drug-associated deaths in Korea. Ann N Y Acad Sci 2004;1025:458-464.

42 Sturluson S: The Younger Edda, also called Snorre's Edda or the Prose Edda, transl by Anderson, RB. Chicago, Scott, Foresman, 1901. http://www.gutenberg.org/etext/18947 (accessed June 12, 2011).

43 Pope HG Jr, Olivardia R, Gruber A, Borowiecki J: Evolving ideals of male body image as seen through action toys. Int J Eat Disord 1999;26:65-72.

-44 Pope HG Jr, Olivardia R, Borowiecki JJ, Cohane GH: The growing commercial value of the male body: a longitudinal survey of advertising in women's magazines. Psychother Psychosom 2001;70:189-192.
45 Pope HG Jr, Phillips K, Olivardia R: The Adonis Complex. The Secret Crisis of Male Body Obsession. New York, Simon and Schuster, 2000.

46 Anonymous: Kojiki. Record of Ancient Matters, transl by Chamberlain, BH. Rutland, Charles E Tuttle, 1981.

47 Yang CF, Gray P, Pope HG Jr: Male body image in Taiwan versus the West: Yanggang Zhiqi meets the Adonis complex. Am J Psychiatry 2005; 162:263-269.

48 Confucius: The Analects, transl by Lau, DC. New York, Penguin, 1979.

-49 Pope HG Jr, Gruber AJ, Mangweth B, Bureau B, de Col C, Jouvent R, Hudson JI: Body image perception among men in three countries. Am J Psychiatry 2000;157:1297-1301.

50 Kanayama G, Pope HG Jr: Gods, men, and muscle dysmorphia. Harv Rev Psychiatry 2011;19:95-98.

51 Fava GA: Morselli’s legacy: dysmorphophobia. Psychother Psychosom 1992;58:117-118.

52 Snaith P: Body image disorders. Psychother Psychosom 1992;58:119-124.

53 Kowner R: When ideals are too 'far off': physical self-ideal discrepancy and body dissatisfaction in Japan. Genet Soc Gen Psychol Monogr 2004;130:333-361.

54 Lerner RM, Iwawaki S, Chihara T, Sorell GT: Self-concept, self-esteem, and body attitudes among Japanese male and female adolescents. Child Dev 1980;51:847-855.

55 Sano A, Le DS, Tran MH, Pham HT, Kaneda M, Murai E, Kamiyama H, Oota Y, Yamamoto S: Study on factors of body image in Japanese and Vietnamese adolescents. J Nutr Sci Vitaminol (Tokyo) 2008;54:169-175.

56 Yuasa Y: The Body, Self-Cultivation, and KiEnergy, transl by Nagamoto S, Hull M. Albany, State University of New York Press, 1993.

57 Minamoto R: A study of practical learning in the beginning of the modern period (in Japanese). Tokyo, Sōbunsha, 1980.

58 Mangweth B, Pope HG Jr, Kemmler G, Ebenbichler C, Hausmann A, de Col C, Kreutner B, Kinzl J, Biebl W: Body image and psychopathology in male bodybuilders. Psychother Psychosom 2001;70:38-43.

59 Chisuwa N, O’Dea JA: Body image and eating disorders amongst Japanese adolescents: a review of the literature. Appetite 2010;54: 5-15.

60 Kayano M, Yoshiuchi K, Al-Adawi S, Viernes N, Dorvlo AS, Kumano H, Kuboki T, Akabayashi A: Eating attitudes and body dissatisfaction in adolescents: cross-cultural study Psychiatry Clin Neurosci 2008;62:17-25.

-61 Chen H, Jackson T: Prevalence and sociodemographic correlates of eating disorder endorsements among adolescents and young adults from China. Eur Eat Disord Rev 2008; 16:375-385.
62 Tong J, Miao SJ, Wang J, Zhang JJ, Wu HM, Li T, Hsu LK: Five cases of male eating disorders in Central China. Int J Eat Disord 2005; 37:72-75.

63 Mangweth B, Pope HG Jr, Hudson JI, Olivardia R, Kinzl J, Biebl W: Eating disorders in Austrian men: an intracultural and crosscultural comparison study. Psychother Psychosom 1997;66:214-221.

64 Herodotus: Readings in Ancient History, vol I, transl by Rawlinson G. Boston, Allyn and Bacon, 1912.

65 Halpern JH: Hallucinogens: an update. Curr Psychiatry Rep 2003;5:347-354.

- 66 Halpern JH, Sherwood AR, Hudson JI, Yurgelun-Todd D, Pope HG Jr: Psychological and cognitive effects of long-term peyote use among Native Americans. Biol Psychiatry 2005;58:624-631.

67 Pope HG Jr: Tabernanthe iboga: an African narcotic plant of social importance. Econ Bot 1969;23:174-184.

68 Suwaki H: Substance-abuse trends in Japan. Public Health Rev 1983;11:199-222.

69 Fendrich M, Johnson TP: Race/ethnicity differences in the validity of self-reported drug use: results from a household survey. J Urban Health 2005;82(suppl 3):iii67-iii81.

70 Greely H, Sahakian B, Harris J, Kessler RC, Gazzaniga M, Campbell P, Farah MJ: Towards responsible use of cognitive-enhancing drugs by the healthy. Nature $2008 ; 456$ : 702-705.

71 Kennett GA, Clifton PG: New approaches to the pharmacological treatment of obesity: can they break through the efficacy barrier? Pharmacol Biochem Behav 2010;97:63-83.

72 Cyranoski D: Malaysian researchers bet big on home-grown Viagra. Nat Med 2005;11: 912.

73 Deluca P, Schifano F: Searching the Internet for drug-related web sites: analysis of online available information on ecstasy (MDMA). Am J Addict 2007;16:479-483.

74 Fox N, Ward K, O’Rourke A: Pro-anorexia, weight-loss drugs and the internet: an 'antirecovery' explanatory model of anorexia. Sociol Health Illn 2005;27:944-971.

75 Halpern JH, Pope HG Jr: Hallucinogens on the Internet: a vast new source of underground drug information. Am J Psychiatry 2001;158:481-483.

76 Hesse M: Enhancement drugs: are there limits to what we should enhance and why? BMC Med 2010;8:50 